\title{
AN EVIDENCE BASED DIMINUTIVE MODEL FOR DIAGNOSIS OF NILIKA- TYPE OF SKIN DISORDER IN AYURVEDA
}

\section{Rupashri Nath*}

Assistant Professor, Department of Roga Nidana and Vikriti Vigyana, Uttarakhand Ayurveda University, Harrawala, Dehradun- 248001, India. ${ }^{*}$ Corresponding Author

Associate professor, All India Institute of Ayurveda, New Delhi- 110076, India.

Sisir Kumar Mandal

ABSTRACT

The disease Nilika is a type of kshudra kustha (group of skin disorders), mentioned in Ayurveda. It may manifests with various sign and symptoms like Krishna (Blackish discoloration), Nirujatanu (painless thin lesion) that may generally manifests in Gatra mukha i.e. whole body and face. In Ayurveda there is no such standard parameter to diagnose this diseases easily. The present endeavor has been made to develop an arbitrary grading system based on classical diagnostic outline mentioned in classical texts of Ayurveda. The effort has also given to understand the savagery of this disease with the help of its elementary sign and symptoms. All the classical metaphors available on Nilika mentioned in classical texts were analyzed and envision features were documented in the structure of photography to diagnose the disease precisely. Further validation of this groundwork of grading system should be confirmed in large scale clinical study.

\section{KEYWORDS : Nilika, Diagnosis, Grading, Lichen planus, Ayurveda}

\section{INTRODUCTION}

In Ayurveda Nilika has been described under kshudra kushtha ( skin disorder). As per ancient scholars of Ayurveda, it is a type of kshudra roga ( $\sim$ minute illness); here kshudra is described on the basis of hetu (etiology), lakshana (symptoms) and cikitsa (treatment). These are exemplifying abruptly in the classical texts, hence known as kshudra. ${ }^{[1]}$ The disease Nilika is occurred due to vitiated vata and pitta. ${ }^{[2]}$ Both the dosha are responsible for manifestation of the disease, they are aggravated due to different manasika nidana (psychological phenomenon) and lodges into the gatra and mukha bhaga (entire body and face). This pathogenesis is characterized by few limited signs and symptoms as mentioned in Classical texts of Ayurveda, like- Krishna (blackish discoloration), Nirujatanuka (painless thin lesion), in Gatra Mukha (Body and face). ${ }^{[3]}$ As the disorder is described under the heading of Kshudra roga, therefore a very short descriptions of nidana (etiology), lakshana (sign and symptoms) and treatment principles are available in Classics. According to Ayurveda vitiated vata, pitta and rakta are prime pathological factors for manifestation of this disease. Rakta is the dhatu (body tissue), which is responsible for coloration of the body. ${ }^{[4]}$ Any physiological alteration of Raktadhatu may inexact the normal sketch of the body and assist to manifest the different altered coloration of body and produce several symptoms. According to contemporary science, this phenomenon can be correlated with the conditions like Lichen planus pigmentosus which is characterized by persistent and asymptomatic, slate gray pigmentation with mild itching.$^{[5]}$ It is specially occurred in middle age and slightly greater incidence in females. ${ }^{[6]}$ Lichen planus pigmentosus is the dermal pigmentation and occurs without any clinical evidence of inflammation. This is thought to be a type hypersensitivity IV reaction to unknown antigen with lichenoid inflammation, leading to melanin incontinence and superficial dermal pigmentation. ${ }^{[7]}$ There is also no such specific treatment to exterminate this pathological phenomenon. This ailment should not be treated simply as an ornamental entity as it habitually prompts emotional agony too. ${ }^{[2]}$ Therefore a classical framework for suitable diagnosis and accurate treatment of this disease is imperative now days. It is possible if the physician have proper understanding regarding the pathological progression of the disease with clinical demonstration of sign and symptoms. Based on such phenomenon the treatment principle of the illness should be applied clinically.
As the disease Nilika is categorized under yapya vyadhi (intake of medicine and diet can symptomatically improve the pathological condition only) and treatment remedies are also minimum. Hence there is need of unique awareness on this aesthetic sickness. Such kind of beautifying problems are very frequent issue now days. To control this problem, proper diagnosis with severity of the disease is very essential. ${ }^{[8]}$ For this purpose, the present study has been carried out to make $a$ classical diagnostic outline of the disease Nilika and to understand the ferociousness of this dermatological disorder with the help of its fundamental sign and symptoms. Literary resources were analyzed in this study. All the data concerning features of Nilika mentioned in classical Ayurveda texts were collected and ancient diagnostic features were documented in the form of photography to diagnose the disease accurately.

\section{BASIC INFORMATION IN CLASSICAL TEXTS: ${ }^{\text {[9] }}$ [NAMC code:} O-26 Nilika (black patch)] ${ }^{[19]}$

- Manasika nidana (mental etiology): Krodha

- Predominance of Dosha (Pathological factors): Pitta and Rakta Prakopaka (Vitiates Pitta and Rakta)

- Signs and symptoms:

गात्रे कृष्णा मण्डलः Black coloured cicular lesion on body.

मुखे कृष्णा मण्डलः Black coloured circular lesion on face.

नीरुज मण्डलः Painless circular lesion

तनुक: Thin lesion over body or face

Flow chart-1, Pathological description of Nilika: ${ }^{[2]}$

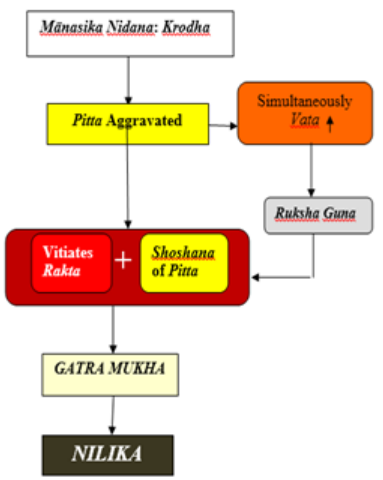


METHODS OBTAINED FOR ASSESSMENT OF NILIKA: Appropriate literary meanings of the features Nilika were reviewed by the preliminary approach of arbitrary grading system and with the aid of taken photography of the patients. Written consent of the patient was taken before capturing the photograph. Special attention has been provided for maintaining privacy of each patient. ${ }^{[10]}$

\section{ARBITRARY GRADING ON VARIOUS CLASSICAL} SYMPTOMS OF NILIKA:

Table-1: Arbitrary grading on the symptom Krishna: [Asita Krishna $^{[11]}=$ Black color lesion over skin]

\begin{tabular}{|l|l|}
\hline FEATURES & SCORE \\
\hline a. Deep black color lesion over skin. & 4 \\
\hline b. Moderate black color lesion over skin. & 3 \\
\hline c. Light black color lesion over skin. & 2 \\
\hline d. Faint black color lesion over skin. & 1 \\
\hline e. Normal color. & 0 \\
\hline
\end{tabular}

Table-2: Arbitrary grading on the symptom Nirujatanu: [Nirujam arujam, Tanu abahalam ${ }^{[12]}=$ Thin skin with devoid of pain]

\begin{tabular}{|l|l|}
\hline FEATURES & SCORE \\
\hline $\begin{array}{l}\text { a. Thin skin without any pain present more than } \\
4 \% \text { surface area of the body. }\end{array}$ & 4 \\
\hline $\begin{array}{l}\text { b. Thin skin without any pain present 3 to } 4 \% \\
\text { surface area of the body. }\end{array}$ & 3 \\
\hline $\begin{array}{l}\text { c. Thin skin without any pain present } 1 \text { to } 2 \% \\
\text { surface area of the body. }\end{array}$ & 2 \\
\hline $\begin{array}{l}\text { d. Thin skin without any pain present less than } \\
1 \% \text { surface area of the body. }\end{array}$ & 1 \\
\hline e. Not occurs. & 0 \\
\hline
\end{tabular}

Table-3: Arbitrary grading on the symptom Gatra Mukha: (Body and face)

\begin{tabular}{|l|l|}
\hline FEATURES & GRADE \\
\hline $\begin{array}{l}\text { a. Lesions are presented in more than } 4 \% \text { surface } \\
\text { area of the body. }\end{array}$ & 4 \\
\hline $\begin{array}{l}\text { b. Lesions are presented in 3 to 4\% surface area } \\
\text { of the body. }\end{array}$ & 3 \\
\hline $\begin{array}{l}\text { c. Lesions are presented in 1 to 2\% surface area } \\
\text { of the body. }\end{array}$ & 2 \\
\hline $\begin{array}{l}\text { d. Lesions are presented in less than 1\% surface } \\
\text { area of the body. }\end{array}$ & 1 \\
\hline e. Not present. & 0 \\
\hline
\end{tabular}

Table-4: Assessment of grading and remarks:

\begin{tabular}{|c|c|c|c|}
\hline Grade & Grade & Sign & Remarks \\
\hline & & & \\
\hline G4 & 4 & ++++ & Very severe \\
\hline G3 & 3 & +++ & severe \\
\hline G2 & 2 & ++ & Moderate \\
\hline G1 & 1 & + & Mild \\
\hline G0 & 0 & Nil & Normal \\
\hline
\end{tabular}

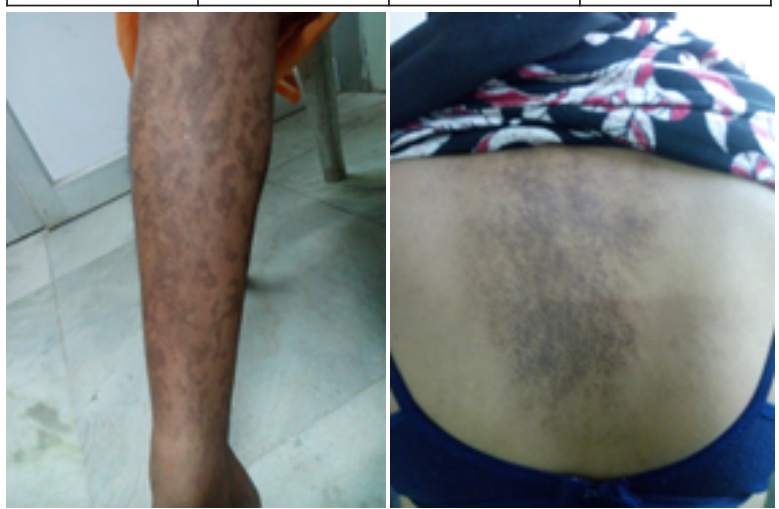

Figl: Krishna Varna (dark patches)

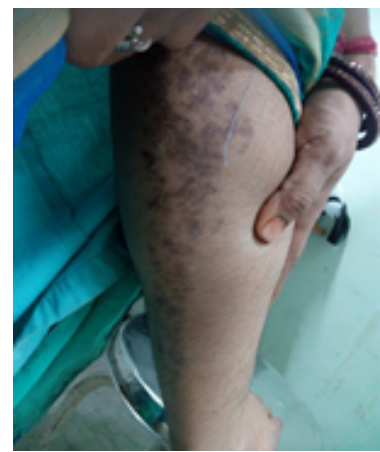

Fig 3: Krishna, Niruja tanu, Gatra

(Dark and painless patches in the body)

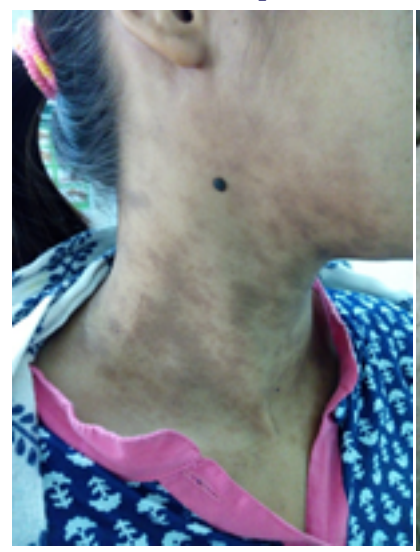

Fig 5: Gatramukha (Dark patches in the body and face)

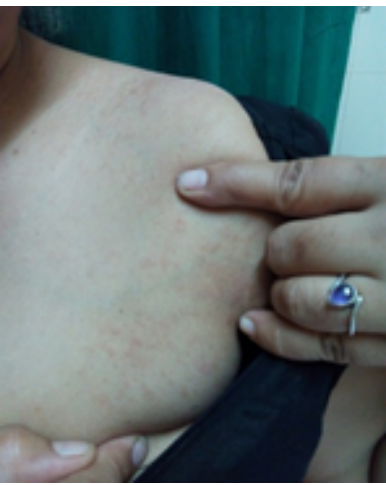

Fig 7: Grade 2 Gatra

(Grade-2: Dark patches in the body

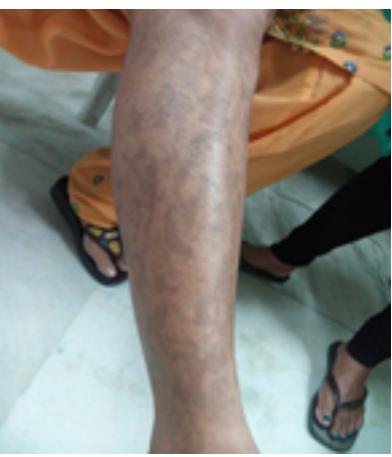

Fig 9: Grade 3 Gatra

(Grade-3: Dark patches in the body)

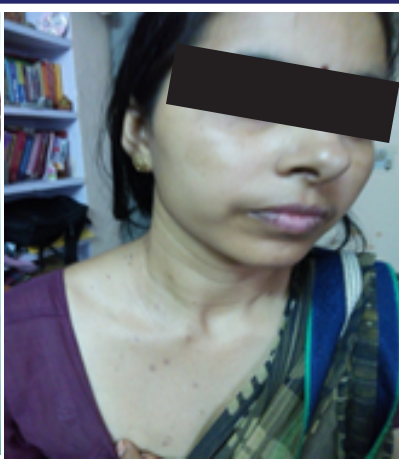

Fig 4: Gatramukha

(Dark patches in the body and face)

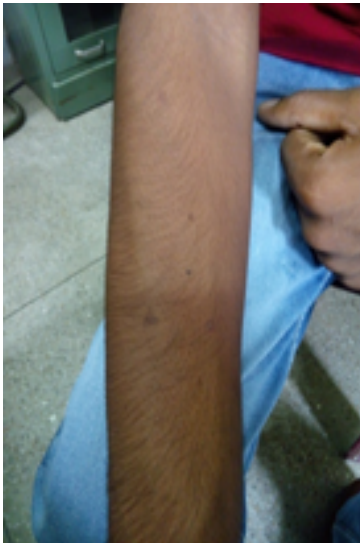

Fig 6: Grade 1 Gatra

(Grade-1: Dark patches in the body)

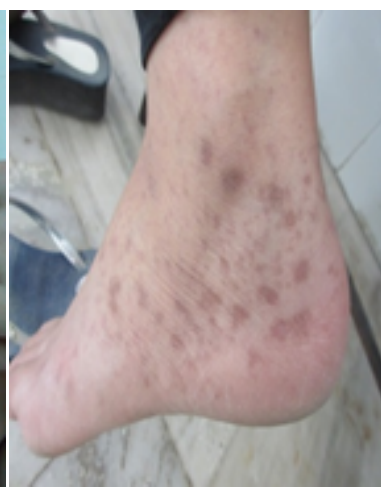

Fig 8: Grade 2 Gatra

(Grade-2: Dark patches in the body)

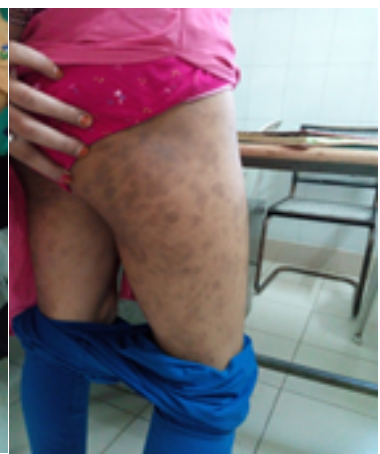

Fig 10: Grade 4 Gatra (Grade-4: Dark patches in the body) 
DISCUSSION

For analysis of the diseases the appropriate commencement in relation to sign and symptoms are very crucial. ${ }^{[13-15]}$ In Ayurveda there are no such standard parameter to identify the severity of this pathological phenomenon. Hence the arbitrary grading has been taken to identify the severity of this ailment. Every sign and symptoms were analyzed based on suitable literary connotation and grading has been prepared to rationalize the disease model as well as for prognostic intention (Table 1-3). As it is well known if all the sign and symptoms are presents at a time in a painstaking disease then it is incurable, but it may be controlled when the physician can impede the severity of sign and symptoms. ${ }^{[14]}$ In the present study Grade 0 is indicating the absence of symptoms, Grade 1 is pertinent for mild condition, Grade 2 for moderate condition, and Grade 3 is applied for severe condition and Grade 4 for very severe condition of the disease (Table 4). Visual authentication i.e. photography (Fig.l-10) were acknowledged here since no such laboratorial parameter are obtainable to recognize such kind of skin lesion.

The primary goal of Ayurveda is to prevent the disease as well as cure the diseases. The classical treatment principles are rightly applicable when physicians are able to diagnose the diseases appropriately. This is attainable when the physician is impeccable in sequence of the fundamental pathological evolution and the severity of sign and symptoms of the diseases. ${ }^{[16-18]}$ Therefore this preliminary diagnostic approach through the arbitrary grading system is incorporated in this small study which is groundwork to offer an outline for the exact diagnosis as well as the treatment of the disease Nilika. Additional meticulous study should be intended in order to organize and endorse this preliminary approach.

\section{ACKNOWLEDGEMENT:}

The authors are highly grateful to all the participants those who were given consent and provided their free hand support for this study.

\section{REFERENCES}

[1] Shreekanthadatta, Commentator. Madhava Nidana of Madhavakar, Reprint ed., Ch.55, Ver.1. Varanasi: Chaukhamba Orientalia, 2010; p.303.

[2] Shreekanthadatta, Commentator. Madhava Nidana of Madhavakar, Reprint ed., Ch.55, Ver.40. Varanasi: Chaukhamba Orientalia, 2010; p.313.

[3] Acharya JT, editor. Madhava Nidana of Madhavakar, Reprint ed., Ch.55, Ver.40. Varanasi: Chaukhamba Orientalia 2010; p.313.

[4] Acharya JT, editor. Sushruta Samhita of Sushruta, Sutra Sthana. Reprint ed. Ch. 13, Ver.15. Varanasi: Chaukhambha Surbharati Prakashan, 2008; p.324.

[5] Rieder E, Kaplan J, Kamino H, Sanchez M, Pomeranz MK. Lichen planus pigmentosus. Dermatol online J. 2013; 19:20713.

[6] Sehgal VN, VermaP, Bhattacharya SN, Sharma S, Rasool F, Lichen Planus Pigmentosus. Skinmed .2013; 11:96-103.

[7] Irene Mathews, Devinder Mohan Thappa, Nidhi Singh, Debasis Gochhait. Lichen planus pigmentosus: a short review. Pigment International. 2016; 3:5-10.

[8] Rupashri Nath, Sisir Kumar Mandal. "Classical diagnostic approach of the disease Vyanga (A type of dermatological disorder)". Journal of Scientific and Innovative Research 2017; 6(4): 135-137.

[9] Acharya JT, editor. Sushruta Samhita of Sushruta, Sutra Sthana. Reprint ed., Ch.21, Ver.21, 25. Varanasi: Chaukhambha Surbharati Prakashan, 2008; p.103-104.

[10] Rupashri Nath, Sisir Kumar Mandal. "A view on classical diagnostic advance of Dadru kushtha (type of skin disorder)". International Journal of Current Research. 2017; 9 (10): 59913-59916.

[11] Vachsapati, Commentator. Madhava Nidana of Madhavakar, Reprint ed., Ch.52, Ver.20. Varanasi: Chaukhamba Orientalia, 2010; p.296.

[12] Gayadas, Commentator. Sushruta Samhita of Sushruta, Nidana Sthana. Reprint ed., Ch.13, Ver.41. Varanasi: Chaukhambha Surbharati Prakashan. 2008; p.323 and Chakrapa idatta, Commentator. Charaka Samhita of Agnivesha, Cikitsa Sthana. Reprint ed., Ch.12, Ver.12. Varanasi: Chaukhambha Prakashan, 2011; p. 483

[13] Nath R, Mahajon B, Mandal SK, Sengupta A, Chattopadhyay A. Efficacy of Pippali (Fruits of Piper longum Linn.) in Grahaniroga: A Prospective Open label Clinical Trial. Journal of Ayurveda Medical Sciences. 2017;2(2):197-203.

[14] Rupashri N, Bidhan M, Apala S, Abichal C. Clinical Examination of Bala (Strength). Unique Journal of Ayurvedic and Herbal Medicines. 2015; 03(04):103-108

[15] Nath R, Mahajon B, Mandal SK, Sengupta A, Chattopadhyay A. Manifestation of sign and symptoms in agnidu hi. Int. J. Res. Ayurveda Pharm. 2016;7(Suppl 2):150-153 http://dx.doi.org/10.7897/2277-4343.07276.

[16] Nath R, Mandal SK, Mahajon B. Rational diagnostic advance of Kushtha (integumentary diseases) by a preliminary arbitrary grading system based on Ayurveda fundamental principles. Journal of Scientific and Innovative Research. 2019;8(2):37-45.
[17] Nath R, Mahajon B, Sengupta A, Chattopadhyay A. Importance of Nidana (Ayurvedic diagnosis) for treatment of an anonymous disease in Ayurveda: $\mathrm{C}$ case study. Journal of Ayurvedic and Herbal Medicine. 2016;2(1):3-5.

[18] Sharma BS, Mahajon B, Rao BCS, et al. Study Protocol of a Prospective, Openlabel, Single-arm, Clinical Trial to Evaluate the Efficacy of Classical Ayurveda Medicines in the Management of Vicharchika (Atopic Eczema). J Res Ayurvedic Sci. 2019;3(1):27-33.

[19] CCRAS, Ministry of AYUSH, NNAMASTE PORTAL (National Ayush Morbidity and Standardized Terminologies Electronic Portal). Available athttp://namstp.ayush.gov.in/\#/index. 